\title{
PENGGUNAAN TEPUNG KULIT UBI KAYU FERMENTASI DALAM FORMULASI PAKAN IKAN NILA
}

\author{
Zafril Imran Azwar") dan Irma Melati"*) \\ ") Pusat Penelitian dan Pengembangan Perikanan Budidaya \\ Jl. Ragunan 20, Pasar Minggu, Jakarta Selatan 12540 \\ E-mail:zapril_ia@yahoo.com \\ *) Balai Penelitian dan Pengembangan Budidaya Air Tawar \\ Jl. Raya Sempur No. 1, Bogor 16154
}

(Naskah diterima: 8 Desember 2011; Diterima publikasi: 9 Agustus 2012)

\begin{abstract}
ABSTRAK
Kulit ubi kayu (Manihot esculenta Crantz) dipertimbangkan sebagai bahan baku pakan yang potensi ketersediaannya sangat tinggi. Di Indonesia produksi ubi kayu mencapai 20 juta ton/tahun dan $23 \%$ dari nilai tersebut adalah kulit ubi kayu. Tertarik dengan hal tersebut dilakukan penelitian kemungkinan pemanfaatan tepung kulit ubi kayu dalam formulasi pakan ikan nila. Kulit ubi kayu yang digunakan direbus terlebih dahulu, kemudian dikeringkan dan ditepungkan menjadi halus. Setelah halus, tepung kulit ubi kayu difermentasi dengan menggunakan mikroba Aspergillus niger dengan tujuan meningkatkan kualitasnya. Setelah difermentasi selama 5 hari, bahan dikeringkan dengan sinar matahari dan ditepungkan kembali. Sebagai perlakuan dalam percobaan adalah dosis tepung kulit ubi kayu dalam formulasi pakan yaitu: $0 \%$ (kontrol), 16\%, 32\%, dan $48 \%$. Protein pakan dibuat $27 \%$ dan lemak tidak lebih $6 \%$ (SNI pakan Nila). Ikan uji yang digunakan adalah benih ikan nila ukuran bobot $11,11 \pm 0,99 \mathrm{~g} / \mathrm{ekor}$. Ikan dipelihara dengan kepadatan 15 ekor/bak beton ukuran 1,0 $\mathrm{m} \times 0,6 \mathrm{~m} \times 0,8 \mathrm{~m}$, dan dirancang dengan sistem resirkulasi. Selama percobaan ikan diberi pakan pelet formulasi sesuai dengan perlakuan sebanyak $4 \%$ dari bobot badan/hari. Masing-masing perlakuan percobaan diulang tiga kali, dan lama percobaan 30 hari. Parameter yang digunakan untuk evaluasi adalah laju pertumbuhan spesifik, penambahan bobot, FCR, retensi protein, dan lemak. Hasil percobaan memperlihatkan bahwa laju pertumbuhan spesifik ikan nila yang diberi pakan dengan menggunakan tepung kulit ubi kayu terfermentasi hingga $16 \%$ tidak berbeda nyata dengan perlakuan kontrol $(P<0,05)$, namun semakin tinggi penggunaan tepung kulit ubi kayu semakin turun laju pertumbuhan spesifik. Demikian juga kaitan dengan konversi pakan (FCR), retensi protein (RP), dan retensi lemak (RL). FCR kontrol sebesar 1,54 20,23 ; penggunaan tepung kulit ubi kayu $16 \%$

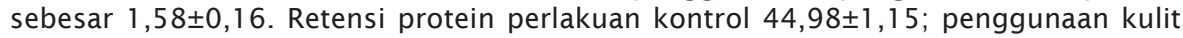
ubi kayu $16 \%$ sebesar $41,04 \pm 5,60$.
\end{abstract}

KATA KUNCl: kulit ubi kayu, Aspergillus niger, submerged fermentation, ikan nila

ABSTRACT: Utilization of fermented cassava peel in artificial feed formuIation for nile tilapia. By: Zafril Imran Azwar and Irma Melati

The cassava (Manihot esculenta Crantz) peel are considered to be the raw material which has sufficiently high potential availability. The production of cassava in Indonesia reaches a level 20 million tons/year and 23\% of this tonnage is cassava peel to constitute waste material. This significant availability of cassava peel waste 
has prompted the carrying out of a research to evaluate the possibility of utilizing cassava peel as an ingredient in feed formulation for the nile tilapia. The cassava peel used in the experiment were first boiled then dried and made into fine-sized meal. This meal was then fermented for 5 days using the fermenting microbe Aspergillus niger in order to improve its quality then sun dried and again made into meal. The dietary treatments tested in the experiment were dosages of the cassava peel meal in the feed pellet formulation, namely: 0\% (as the control), 16\%, 32\%, and $48 \%$. The protein levels of the treatments were maintained at $27 \%$ and the fat levels at not higher than 6\% (i.e., the national standard SNI for the feed of red Nile tilapia). The test fish were nile tilapia fry of individual weights $11.11 \pm 0.99 \mathrm{~g}$. The fish were stocked at a stocking density of 15 fish per concrete tank measuring $1.0 \mathrm{~m} \times 0.6 \mathrm{~m}$ $x 0.6$ meter provided with a recirculating system. During the experiment, the fish were fed the respective experimental diet at a daily feeding rate $4 \%$ of total body weight. Each dietary treatment had three replicates. The duration of experiment was 30 days. The parameters for evaluation of the effects of dietary treatments were specific growth rate, body weight gain, FCR, retentions of protein, and fats. Results of the experiment showed that the specific growth rate of the nile tilapia fed diets containing fermented cassava peel meal at levels up to $16 \%$ were not significantly different from that of the control fish $(P>0.05)$ but the increasing dietary levels of fermented cassava peel meal tended to give decreasing specific growth rates. So were with the $F C R$, the protein retention $(P R)$, and the fat retention $(F R)$. The FCR of the control was $1.54 \pm 0.23$, that of the diet containing $16 \%$ fermented cassava peel meal $1.58 \pm 0.16$. The protein retention for the control diet was $44.98 \pm 1.15$, that of the diet containing $16 \%$ fermented cassava peel meal was $41.04 \pm 5.60$.

\section{KEYWORDS: cassava peel, Aspergillus niger, submerged fermentation, nile tilapia}

\section{PENDAHULUAN}

Harga pakan ikan dari tahun ke tahun terus meningkat tanpa diimbangi peningkatan harga jual ikan yang berarti, sehingga profit yang diterima petani semakin menurun. Sebagai catatan untuk komoditas ikan nila yang dibudidayakan di kolam untuk 3 musim tanam dengan konversi pakan 1,3 diperhitungkan bahwa biaya yang dikeluarkan untuk pakan ikan terhadap biaya produksi telah mencapai $81,0 \%$; dan biaya pengadaan benih hanya mencapai 8,0\% (Ismunaji, 2009). Kondisi ini dapat mempengaruhi intensitas usaha budidaya yang berakibat menurunkan produksi nasional. Banyak faktor yang menyebabkan tingginya harga pakan antara lain; tata niaga yang kurang efisien, ketidakmampuan modal petani sehingga pembelian pakan sistem yarnen (Bayar Panen), dan ketergantungan pada bahan baku impor. Hampir sebagian besar bahan baku pakan untuk pembuatan pakan ikan yang diproduksi oleh industri pakan komersial diperoleh dari impor.

Dua bahan utama yang paling dominan diimpor, yaitu tepung ikan dan tepung bungkil kedelai dan keduanya merupakan bahan baku pokok sumber protein yang cukup mem- pengaruhi harga pakan ikan (60\%). Tepung ikan sebagian sudah diperoleh dari lokal, sedangkan tepung ikan import umumnya digunakan untuk formulasi pakan ikan laut dan udang. Pemakaian tepung kedelai dalam ransum ikan cukup tinggi maksimal dapat mencapai 35\% tergantung spesies ikan. Hampir 100\% tepung bungkil kedelai yang digunakan dalam formulasi pakan ikan juga merupakan bahan impor. Berdasar fakta di atas maka perlu dicarikan alternatif menekan impor bahan baku dengan cara mereduksi pemakaian bahan baku impor dengan bahan lokal.

Sebagai negara agraris, Indonesia memiliki potensi bahan baku nabati yang cukup besar antara lain daun lamtoro, Azoola pinata, Lemna sp., biji kapuk, kecipir (protein lebih dari 20\%), dan ubi kayu serta produk sampingannya, bungkil sawit, jagung, dedak (kandungan protein di bawah 20\%). Khusus untuk ubi kayu produksinya hampir mencapai 20 juta ton/ tahun dan $23 \%$ dari produk tersebut atau lebih dari 4 juta ton adalah hasil sampingan, yang terbuang (BPS, 2008 dalam Busairi \& Hersoelistyorini, 2009). Dari beberapa penelitian tercatat bahwa beberapa bahan baku limbah pertanian maupun produk pertanian bentuk biji-bijian, kualitas, dan ketersediaan 
nutrisinya dapat ditingkatkan dalam proses fermentasi oleh berbagai mikroba. Kulit ubi kayu mengandung protein yang rendah (4\%$5 \%$, namun nilainya lebih tinggi dari ubi kayu sendiri. Menurut Aderemi et al. (2006), beberapa isolat mikroba dapat digunakan untuk memperbaiki nilai gizi tepung kulit ubi kayu. Hasil percobaan Azwar \& Melati (2010) memperlihatkan bahwa fermentasi tepung kulit ubi kayu dengan menggunakan mikroba Aspergillus niger, Trichoderma viride, dan ragi tape masing-masing meningkatkan protein dari 5,6\% menjadi 20,35\% (5 hari inkubasi); $23,42 \%$ (7 hari inkubasi); dan 18,16\% (8 hari inkubasi). Percobaan Ezeklel et al. (2010) juga mencatat terjadi peningkatan protein kulit ubi kayu dari 4,27\% menjadi $38,52 \%$ setelah difermentasi dengan menggunakan Trichoderma viride.
Tertarik dengan upaya mencari bahan baku lokal alternatif yang potensial untuk pakan ikan maka dilakukan suatu percobaan kemungkinan pemanfaatan tepung kulit ubi kayu yang telah mengalami proses fermentasi untuk formulasi pakan ikan nila.

\section{BAHAN DAN METODE}

Kulit ubi kayu diperoleh dari hasil sampingan pabrik tapioka di wilayah Bogor. Kulit dipotong kecil-kecil, kemudian dikukus untuk menghilangkan kandungan sianida (hilang 90\%) dan dikeringkan dengan memanfaatkan sinar matahari. Setelah kering kulit ubi kayu ditepungkan dengan menggunakan mesin penepung "Hammer mill". Tepung kulit ubi kayu difermentasi dengan menggunakan

Tabel 1. Komposisi bahan baku (\%) dan hasil analisis proksimat pakan uji

Table 1. Ingredients composition (\%) and proximate composition

\begin{tabular}{lcccc}
\hline \multicolumn{1}{c}{$\begin{array}{c}\text { Bahan baku } \\
\text { Ingredients }\end{array}$} & \multicolumn{4}{c}{ Diet } \\
\cline { 2 - 5 } & $\mathbf{1}$ & $\mathbf{2}$ & $\mathbf{3}$ & $\mathbf{4}$ \\
\hline Tepung ikan (Fish meal) & 10 & 10 & 11 & 12 \\
Tepung bungkil kedelai (Soybean meal) & 32 & 26 & 20 & 14 \\
Dedak (Rice brain) & 40 & 32 & 22 & 12 \\
Tepung kulit ubi kayu F*) (Cassava peel meal) F*) & - & 16 & 32 & 48 \\
Tapioka (Cassava meal) & 10 & 10 & 9.65 & 8.03 \\
Premix (Vitamin mix) & 2 & 2 & 2 & 2 \\
Dikalsium fosfat (Dicalsium phosphate) & 2 & 2 & 2 & 2 \\
Minyak sawit (Palm oil) & 0 & 0.79 & 1.35 & 1.97 \\
Filler & 4 & 1.21 & 0 & 0 \\
\hline & 100 & 100 & 100 & 100 \\
\hline Komposisi proksimate (Proximate composit ion ): & & & & \\
Kadar air (Moisture) (\%) & 4.50 & 4.80 & 6.40 & 6.30 \\
Protein (Crude protein) (\%) & 25.20 & 26.60 & 25.43 & 25.28 \\
Lemak (Crude lipid) (\%) & 6.30 & 7.90 & 7.87 & 7.49 \\
Abu (Ash) (\%) & 10.50 & 11.43 & 12.03 & 14.15 \\
Serat kasar (Crude fibre) (\%) & 5.69 & 8.26 & 12.48 & 17.07 \\
BETN (Nitrogen Free Extract) (\%) & 52.31 & 45.81 & 43.19 & 37.01 \\
Energi (Energy) (kkal/g) & $2,699.40$ & $2,716.10$ & $2,604.40$ & $2,416.20$ \\
Protein/energi rasio (Protein/energy ratio) (\%) & 10.71 & 10.21 & 10.24 & 9.55 \\
\hline
\end{tabular}

Keterangan (Note):

*) $\mathrm{F}=$ Difermentasi (Fermented)

**) Total energi tercerna (DE) dihitung berdasarkan: protein 3,5 kkal/g; lemak 8, $1 \mathrm{kkal} / \mathrm{g}$; bahan ekstrak tanpa nitrogen (BETN) 2,5 kkal/g (Sumber: NRC, 1997) (Total digestible energy calculated based on: protein $3.5 \mathrm{kcal} / \mathrm{g}$, lipid $8.1 \mathrm{kcal} / \mathrm{g}$, nitrogen free extract (BETN) $2.5 \mathrm{kcal} / \mathrm{g}$ (Source: NRC, 1997)) 
mikroba Aspergillus niger pada dosis 3\% (b/b). Waktu fermentasi berlangsung selama 5 hari. Tepung yang dihasilkan dari proses fermentasi digunakan sebagai tepung kulit ubi kayu uji dalam formulasi pakan.

Percobaan uji formulasi dilakukan di dalam bak beton ukuran $1 \mathrm{~m} \times 0,6 \mathrm{~m} \times 0,8 \mathrm{~m}$ (PxLxT). Bak diisi air setinggi $0,6 \mathrm{~m}$, dan dirancang sistem air mengalir melalui teknik resirkulasi. Ke dalam bak ditebar ikan nila dengan bobot

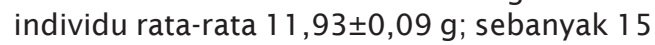
ekor /bak. Sebagai perlakuan dalam percobaan ini adalah dosis tepung kulit ubi kayu fermentasi yaitu; 0\% (kontrol); 16\%, 32\%, dan 48\% dalam formulasi pakan. Pakan uji terdiri atas pakan iso protein berkadar protein $27 \%$ dan lemak sekitar 6\% (SNI, 2009). Formulasi pakan uji disusun dari berbagai bahan baku antara lain tepung ikan, tepung bungkil kedelai, dedak, vitamin mix, minyak nabati, dan tapioka (Tabel 1). Percobaan dilaksanakan selama 30 hari, menggunakan Rancangan Acak lengkap dan masing-masing perlakuan terdiri atas 3 ulangan.

Selama percobaan ikan diberi pakan uji sebanyak 4\% dari bobot biomassa, dan diberikan 3 kali per hari yaitu; pagi, siang, dan sore hari. Jumlah pakan yang diberikan dicatat untuk digunakan dalam perhitungan konversi pakan. Parameter yang diamati adalah bobot ikan awal dan akhir, sintasan, kandungan protein, dan lemak tubuh awal dan akhir. Respons perlakuan dinilai dari laju pertumbuhan spesifik (SGR), penambahan bobot badan, sintasan, retensi protein, dan lemak.

\section{HASIL DAN BAHASAN}

\section{Pertumbuhan}

Hasil percobaan memperlihatkan bahwa laju tumbuh spesifik (SGR) yang dinyatakan dalam \%/hari ikan nila uji memperlihatkan bahwa semakin tinggi penggunaan tepung kulit ubi kayu, laju tumbuh semakin rendah (Tabel 2). Hasil analisis statistik memperlihatkan bahwa ada perbedaan yang nyata $(P<0,05)$ laju tumbuh ikan nila antara perlakuan. Laju tumbuh tertinggi ditemui pada perlakuan kontrol yaitu $1,74 \%$ /hari sedangkan yang paling rendah adalah perlakuan dosis tepung kulit ubi kayu sebesar $48 \%$ yaitu 1,20\%/hari (Tabel 2). Analisis statistik lanjut menunjukkan bahwa laju tumbuh spesifik antara perlakuan kontrol dan perlakuan dosis kulit ubi kayu yang telah difermentasi sebesar $16 \%$ tidak memperlihatkan perbedaan yang nyata $(P>0,05)$; namun keduanya memperlihatkan respons yang berbeda nyata $(P<0,05)$ dengan perlakuan dosis tepung kulit ubi kayu 32\% dan $48 \%$. Sedang respons laju tumbuh spesifik antara perlakuan dosis tepung kulit ubi kayu sebesar $32 \%$ tidak memperlihatkan perbedaan yang nyata $(P>0,05)$ dengan perlakuan dosis tepung kulit ubi kayu $48 \%$. Laju tumbuh spesifik perlakuan pakan formulasi dengan penggunaan tepung kulit ubi kayu 16\% mencapai 1,68\%/ hari.

Tabel 2. Penambahan bobot rata-rata individu, laju tumbuh spesifik (LPS) (\%/hari), sintasan (\%) pada masing-masing perlakuan

Table 2. Average body weight gain, specific growth rate (\%/day), survival rate (\%) at each treatment

\begin{tabular}{cccccc}
\hline $\begin{array}{c}\text { Perlakuan } \\
\text { Treatments } \\
\text { Levels cassava } \\
\text { peel meal in diets) } \\
(\%)\end{array}$ & $\begin{array}{c}\text { Bobot awal } \\
\text { rata-rata } \\
\text { Average } \\
\text { initial } \\
\text { weight } \\
(\mathbf{g})\end{array}$ & $\begin{array}{c}\text { Bobot akhir } \\
\text { rata-rata } \\
\text { Average } \\
\text { final } \\
\text { weight } \\
\mathbf{( g )}\end{array}$ & $\begin{array}{c}\text { Penambahan } \\
\text { bobot } \\
\text { Weight } \\
\text { gain } \\
\mathbf{( g )}\end{array}$ & $\begin{array}{c}\text { Sintasan } \\
\text { Survival } \\
\text { rate } \\
\text { (\%) }\end{array}$ & $\begin{array}{c}\text { Spesific } \\
\text { growth } \\
\text { rate } \\
(\%)\end{array}$ \\
\hline 0 & $12.79 \pm 0.02$ & $20.84 \pm 1.25$ & 8.05 & 92.74 & $1.74 \pm 0.22^{\text {a) }}$ \\
16 & $12.79 \pm 0.02$ & $20.52 \pm 1.43$ & 7.73 & 87.71 & $1.68 \pm 0.25^{\text {a) }}$ \\
32 & $12.78 \pm 0.01$ & $18.82 \pm 0.56$ & 6.04 & 89.71 & $1.38 \pm 0.11^{\text {b) }}$ \\
48 & $12.78 \pm 0.07$ & $17.91 \pm 0.95$ & 5.13 & 78.63 & $1.20 \pm 0.17^{\mathrm{b})}$ \\
\hline
\end{tabular}

Keterangan (Note):

Angka yang diikuti huruf dengan superscript yang sama tidak berbeda nyata $(P<0,05)$

$V$ alues with the same superscript indicated not significantly different $(P>0.05)$ 
Berkaitan dengan laju pertumbuhan spesifik terjadi juga peningkatan penambahan bobot badan individu rata-rata ikan nila uji. Penambahan bobot rata-rata sejalan dengan laju pertumbuhan spesifik, dan penambahan bobot rata-rata individu tertinggi pada perlakuan pakan tanpa kulit ubi kayu yaitu sebesar $8,05 \mathrm{~g}$. Kemudian diikuti dengan perlakuan pakan formulasi dengan menggunakan tepung kulit ubi kayu sebesar $16 \%$ yaitu sebesar $7,73 \mathrm{~g}$. Penambahan bobot menurun sejalan dengan meningkatnya tepung kulit ubi kayu fermentasi dalam ransum pakan dan penambahan bobot rata-rata individu terendah dijumpai pada perlakuan $48 \%$ sebesar $5,13 \mathrm{~g}$. Laju pertumbuhan spesifik ikan uji sebesar 1,68\%-1,74\% ini masih cukup baik dilihat dari laju pertumbuhan spesifik ikan nila dari beberapa percobaan di laboratorium. Laju pertumbuhan spesifik pada perlakuan penggunaan kulit ubi kayu sebanyak lebih $32 \%$ sangat rendah yang mencirikan laju tumbuh yang tidak normal dan ada senyawa tertentu yang mungkin jadi penghambat pertumbuhan. Percobaan Maulana (2011) di laboratorium dengan perlakuan berbagai dosis daun lamtoro dalam formulasi pakan ikan nila, untuk ikan ukuran awal berbobot $10 \mathrm{~g}$ memperlihatkan laju pertumbuhan spesifik terbaik sebesar 1,23\%. Fitriliyani (2010) yang melakukan percobaan penggunaan tepung daun lamtoro yang dihidrolisis dengan enzim cairan rumen dalam pakan ikan nila berprotein sekitar 30\% memperlihatkan bahwa laju tumbuh spesifik berkisar 1,47\%-2,77\% tergantung jumlah daun lamtoro yang digunakan. Sedangkan laju tumbuh ikan nila yang diberi pakan campuran daun lamtoro yang tidak dihidrolisis dengan ekstrak cairan rumen berkisar 1,32\%-1,97\% tergantung dosis tepung daun lamtoro dalam pakan. Percobaan Subagya et al. (1993) mencatat bahwa laju pertumbuhan spesifik ikan nila merah yang dipelihara di keramba jaring apung (KJA) dengan kepadatan berbeda dan diberi pakan buatan komersial berprotein $26 \%$ memperlihatkan laju pertumbuhan spesifik berkisar 2,00\%-2,28\%. Percobaan Anggawati et al. (1993) laju tumbuh ikan nila merah yang dipelihara di KJA ukuran $1 \mathrm{~m} \times 1 \mathrm{~m} \times 1 \mathrm{~m}$ dengan kepadatan $500 \mathrm{~m}^{2}$ dan diberi pakan komersial berprotein 26\% berkisar 2,55\%-2,85\%. Percobaan Jauncy \& Ross (1982) mendapatkan laju pertumbuhan tertinggi pada Sarothelodon mossambiccus pada ukuran 0,5-10 g/ekor sebesar $4 \%$ /hari dengan pemberian pakan berkadar protein $40 \%$, sedangkan ikan nila yang diberi pakan berprotein 25\% laju tumbuh harian dicapai 3,5\%. Kaitan dengan laju tumbuh Weatherley (1972), mengemukakan bahwa padat tebar, terbatasnya ruang gerak ikan, sistem pemeliharaan, jumlah, kualitas pakan, dan cara pemberian pakan sangat mempengaruhi laju tumbuh.

Sintasan ikan nila uji berkisar 78,63\% hingga $92,74 \%$; terbaik pada perlakuan tanpa menggunakan tepung kulit ubi kayu yaitu sebesar $92,74 \%$ dan terburuk pada perlakuan dosis $48 \%$ kulit ubi kayu dalam ransum yaitu sebesar 78,63\%. Namun dari hasil uji statistik tidak terlihat perbedaan sintasan ikan nila uji selama percobaan $(P>0,05 \%)$. Hanya terlihat ada tendensi semakin tinggi penggunaan tepung kulit kayu semakin tinggi tingkat kematian ikan nila uji. Belum diketahui dengan pasti faktor penyebabnya. Kekhawatiran terhadap adanya kandungan sianida dari tepung kulit ubi kayu telah direduksi dengan dilakukan perebusan kulit ubi kayu, kemudian dijemur sebelum diproses penepungan. Dari hasil percobaan diketahui bahwa dengan cara perebusan dan penjemuran kandungan sianida kulit ubi kayu dapat turun hingga $90 \%$. Rizal et al. (2005) telah membuktikan bahwa kandungan sianida daun singkong turun sebesar 83,2\% setelah difermentasi dengan kapang Aspergillus niger. Sehingga penyediaan bahan baku tepung kulit ubi kayu dengan cara di atas terjamin kandungan sianidanya rendah.

\section{Retensi Protein dan Lemak}

Nilai retensi protein dan lemak rata-rata ikan uji disajikan pada Tabel 3. Kisaran retensi protein antara perlakuan adalah $28,34 \%$ hingga 44,98\%; retensi protein menurun dengan meningkatnya penggunaan tepung kulit ubi kayu dalam ransum. Hasil uji statistik memperlihatkan bahwa retensi protein antara perlakuan berbeda nyata $(\mathrm{P}<0,05)$. Retensi protein nyata tertinggi $(P<0,05)$ pada perlakuan tanpa menggunakan tepung kulit ubi kayu (kontrol), namun retensi protein ini tidak berbeda nyata dengan retensi protein pada perlakuan penggunaan tepung kulit ubi kayu fermentasi sebesar $16 \%$. Sedangkan retensi protein pada perlakuan kontrol berbeda nyata dengan perlakuan penggunaan tepung kulit ubi kayu fermentasi sebesar $32 \%$ dan $48 \%$. Retensi protein pada perlakuan penggunaan tepung kulit ubi kayu fermentasi sebesar 16\% tidak berbeda nyata $(P<0,05)$ dengan perlakuan 
Tabel 3. Rata-rata retensi protein dan lemak, konversi pakan pada masingmasing perlakuan

Table 3. Average protein and lipid retention, food convertion ratio (FCR) at each treatment

\begin{tabular}{cccc}
\hline $\begin{array}{c}\text { Perlakuan } \\
\text { Treatments } \\
\text { Level of cassava } \\
\text { peel meal in diets) } \\
\text { (\%) }\end{array}$ & $\begin{array}{c}\text { Retensi protein } \\
\text { Protein } \\
\text { retention } \\
\mathbf{( \% )}\end{array}$ & $\begin{array}{c}\text { Retensi } \\
\text { lemak } \\
\text { Lipid } \\
\text { retention } \\
\mathbf{( \% )}\end{array}$ & FCR \\
\hline 0 & $44.98 \pm 1.15^{\mathrm{a}}$ & $15.52 \pm 2.30^{\mathrm{a}}$ & $1.54 \pm 0.22$ \\
16 & $41.04 \pm 5.60^{\mathrm{ab}}$ & $15.71 \pm 2.18^{\mathrm{a}}$ & $1.58 \pm 0.16$ \\
32 & $38.89 \pm 2.92^{\mathrm{bc}}$ & $12.60 \pm 2.22^{\mathrm{a}}$ & $2.11 \pm 0.19$ \\
48 & $28.34 \pm 3.79^{\mathrm{c}}$ & $11.44 \pm 2.82^{\mathrm{a}}$ & $2.65 \pm 0.13$ \\
\hline
\end{tabular}

Keterangan (Note):

Angka yang diikuti huruf dengan superscript yang sama tidak berbeda nyata $(P<0,05)$ Values with the same superscript indicated not significantly different $(P>0.05)$

penggunaan tepung kulit ubi kayu sebesar $32 \%$, namun berbeda dengan perlakuan tepung kulit ubi kayu sebesar $48 \%$.

Pola dari retensi protein pada perlakuan dalam percobaan ini sangat terkait dengan laju tumbuh spesifik ikan uji (Tabel 2). Ini menunjukkan bahwa penggunaan tepung kulit kayu dalam formulasi pakan dapat hanya dalam jumlah terbatas. Rendahnya retensi protein yang mengakibatkan rendahnya laju tumbuh, disebabkan terbatasnya ketersediaan asam amino tertentu dalam formulasi pakan atau dapat juga terbatasnya asam amino yang dapat diserap dalam sistem pencernaan ikan. Semakin tinggi penggunaan tepung ubi kayu semakin rendah asupan asam amino, sehingga membatasi sintesis protein tubuh. Terbatasnya sintesis protein tubuh akan mempengaruhi laju tumbuh ikan uji. Dalam penelitian ini tidak dilakukan analisis asam amino pakan uji, namun menurut Ezeklel et al. (2010), tepung kulit ubi kayu memiliki asam amino esensial, namun kandungan metionin menunjukkan faktor pembatas, hanya mencapai $60 \mathrm{mg} / 100$ $\mathrm{g}(0,06 \%)$. Sumber asam amino esensial dalam pakan uji adalah tepung ikan dan tepung bungkil kedelai, keduanya masing-masing mengandung metionin sebesar 1,60\% dan 1,38\% (Hertrampf \& Pascual, 2000), sehingga semakin rendah penggunaan tepung kedelai akan menurunkan beberapa asam amino esensial termasuk metionin dan lisin. Suplementasi lisin dan metionin pada pakan dengan kadar protein terbatas memperbaiki pertumbuhan ikan channel catfish (Li \& Robinson, 1998), ikan Mas (Common carp) (Viola \& Lahay, 1991). Ketersediaan metionin sangat penting dalam proses sintesis protein, karena senyawa ini selalu menjadi inisiasi dalam penyusunan protein tubuh. Terbatasnya metionin mengakibatkan penyusunan protein tubuh oleh asam-asam amino yang dimediasi oleh DNA tidak dapat berlangsung (Wolfe, 1983). Ketersediaan asam amino esensial ini akan berpengaruh pada retensi protein sebagai salah satu bentuk cadangan energi. Di mana nilai retensi protein akan mempengaruhi nilai parameter pertumbuhan lain seperti laju pertumbuhan harian (Fitriliyani, 2010). Faktor lain yang menyebabkan rendahnya retensi protein pada perlakuan penggunaan kulit ubi kayu 32\% dan $48 \%$ dalam ransum adalah tingginya serat kasar. Kandungan serat kasar pada perlakuan tepung kulit ubi kayu 32\% dan $48 \%$ adalah masingmasing 12,48\% dan 17,07\%; dan nilai ini jauh lebih tinggi dibandingkan dengan perlakuan dosis 0 (kontrol) dan $16 \%$ masing-masing mencapai 5,69\% dan 8,26\% (Tabel 1). Berdasarkan SNI (2009), kandungan serat kasar dalam pakan untuk ikan nila masing-masing ukuran pendederan dan pembesaran adalah masing-masing tidak lebih dari 6\% dan $8 \%$. Serat kasar mengganggu absorbsi asam amino dalam sistem pencernaan.

Nilai retensi protein ikan uji sebesar 41,04\% dalam percobaan ini cukup tinggi untuk perlakuan penggunaan dosis tepung kulit ubi 
kayu 16\%. Percobaan Fitriliyani (2010) pada ikan nila menggunakan daun lamtoro dalam ransum yang dihidrolisis dengan enzim cairan rumen berbagai dosis memperlihatkan retensi protein berkisar $24,98 \%$ hingga $40,70 \%$. Kurniasih (2010) yang juga menguji formulasi pakan pada ikan nila dengan menggunakan ekstrak enzim proteolitik asal probiotik isolat dari pencernaan lele mendapatkan nilai retensi protein berkisar $40,0 \%$ hingga $50,0 \%$. Sedangkan Gonzales et al. (2007) menggunakan tumbuhan sebagai bahan dasar penyusun pakan larva ikan nila hanya mendapatkan nilai retensi protein sebesar 31,9\%. Ali et al. (2003) pada pakan ikan nila menggunakan alfafa leaf meal pada taraf 5\%, 10\%, $15 \%$, dan $20 \%$ didapatkan nilai retensi protein berturut-turut 35,30\%, 31,80\%; 29,81\%; dan $27,74 \%$. Perbedaan asam amino esensial pakan atau bahan yang digunakan serta ketersediaan asam amino yang dapat diserap oleh sistem sel sangat menentukan retensi protein.

Nilai retensi lemak rata-rata ikan uji dapat dilihat pada Tabel 3. Dosis tepung kulit ubi kayu fermentasi dalam formulasi pakan nyata mempengaruhi retensi lemak $(P<0,05)$. Nilai retensi lemak perlakuan kontrol dan dosis tepung kulit ubi kayu 16\% nyata lebih tinggi $(\mathrm{P}<0,05)$ dibandingkan dengan perlakuan dosis lebih dari $32 \%$. Pada perlakuan kontrol dan dosis tepung kulit ubi kayu 16\% masing-masing retensi lemak sebesar 15,52\% dan 15,71\%; dan nilai ini jauh lebih besar dibandingkan dengan perlakuan dosis tepung kulit ubi kayu $32 \%$ dan $48 \%$ yaitu sebesar $12,60 \%$ dan $11,44 \%$. Semakin tinggi dosis tepung kulit ubi kayu dalam formulasi pakan retensi lemak semakin rendah. Retensi lemak dalam tubuh berkaitan dengan tingginya kadar karbohidrat dan lemak dalam pakan sebagai sumber energi. Kelebihan energi akan diakumulasikan sebagai lemak tubuh dalam proses lipogenesis (Anggorodi, 1995). Retensi lemak yang rendah pada perlakuan penggunaan tepung kulit ubi kayu $32 \%$ dan $48 \%$, mungkin terkait dengan lebih banyaknya pemanfaatan energi dari sumber karbohidrat dan lemak yang tersedia dalam ransum oleh ikan uji, karena terbatasnya energi dari protein. Rendahnya retensi protein pada perlakuan dengan penggunaan tepung kulit ubi kayu 32\% dan 48\% memperlihatkan pemanfaatan energi dari protein sangat terbatas. Ikan nila memiliki kemampuan untuk memanfaatkan karbohidrat kompleks seperti dextrin, starch dibandingkan karbohidrat sederhana seperti glukosa dan maltose. Terbatasnya energi dari protein maka karbohidrat dan lemak yang utama dimanfaatkan sebagai sumber energi. Selain itu, serat makanan akan tinggal dalam saluran pencernaan dalam waktu relatif singkat sehingga absorbsi zat makanan berkurang. Tingginya serat kasar dapat menghambat proses penyerapan lemak serta membantu mengurangi asupan kalori. Semakin tinggi serat kasar semakin banyak porsi lemak makanan terbuang lewat feses. Hal ini mengakibatkan kandungan lemak tersebut dibuang dan tidak diserap tubuh. Dari data analisis proksimat pakan uji terlihat bahwa semakin tinggi pemakaian tepung kulit ubi kayu dalam ransum semakin tinggi kandungan serat kasarnya.

\section{KESIMPULAN}

Dari hasil percobaan ini dapat disimpulkan:

1. Tepung kulit ubi kayu yang difermentasi dengan Aspergillus niger dapat dimanfaatkan sebagai bahan baku pakan ikan nila dalam jumlah terbatas.

2. Tepung kulit ubi kayu yang telah difermentasi maksimal dapat dipakai dalam ransum pakan ikan nila sebesar $16 \%$.

3. Percobaan untuk meningkatan pemanfaatan tepung kulit ubi kayu dalam ransum pakan ikan nila perlu dilakukan melalui pendekatan keseimbangan asam amino esensial dan penurunan serat kasar.

\section{DAFTAR ACUAN}

Ali, A., Al Asgah, N.A., Al-Ogail, S.M., \& Ali, S. 2003. Effect of Feeding different leves of alfalfa meal on the growth performance and body composition of Nile Tilapia (Oreochromis niloticus). Fingerlings. Asian Fisheries Science, 16: 59-67.

Anggarodi, R. 1995. Nutrisi Aneka Ternak Unggas Gramedia. Pustaka Utama. Jakarta, $219 \mathrm{hlm}$.

Anggawati, A.M., Ilyas, S., \& Herawati, E.S. 1993. Strategi pemberian pakan ikan nila merah yang dipelihara dalam Karamba Jaring Apung di Waduk Kedung Ombo: Bulletin Penelitian Perikanan, edisi khusus No 5, Balai Penelitian Perikanan Air Tawar, hlm. 117-133.

Anonim. 2006. "Lele Kampung" dari Kampung Lele. Warta Pasar Ikan. Direktorat Pemasaran Dalam Negeri. Ditjen Pengolahan dan Pemasaran Hasil Perikanan. Departemen Kelautan dan Perikanan, hlm. 1-13. 
Aderemi, F.A., Lawe, T.E., \& lyayi, E.A. 2006. Nutritional Value of Biodegraded Cassava Root Sieviate (CRS) and Its Utilization by Layers. Journal of Food Technology, (2): 216220.

Azwar, Z.I. \& Melati, I. 2010. Perbaikan Kualitas Bahan Baku Pakan (Kulit Ubi Kayu) Menggunakan Teknologi Fermentasi dan Mikroba Serta Pemanfaatannya dalam Formulasi Pakan Ikan Nila. Laporan Hasil Penelitian 2010. Balai Riset Perikanan Budidaya Air Tawar, $13 \mathrm{hlm}$.

Busairi, A.M. \& Hersoelistyorini, W. 2009. Pengkayaan Protein Kulit Ubi Kayu Melalui Proses Fermentasi: Optimasi Nutrien Substrat Menggunakan Respon Surface Methodology. Prosiding Seminar Nasional Teknik Kimia. Bandung, 19-20 Oktober 2009, TPM 17.1-17.7.

Ezeklel, O.O., Aworh, O.C., Blaschek, H.P., \& Ezeji, T. 2010. Protein enrichment of cassava peel by submerged fermentation with Trichoderma viride (ATCC 36316). African Journal of Biotechnology, 9(2): 187-194.

Fitriliyani, I. 2010 . Peningkatan kualitas nutrisi tepung daun lamtoro dengan penambahan ekstrak enzim cairan rumen domba (Ovis aries) untuk bahan pakan ikan nila (Oreochromis niloticus). Disertasi. Sekolah Pascasarjana. IPB, $155 \mathrm{hlm}$.

Gonzales, J.M., Alison, H., Megan, E.R., Todd, F.P., \& Paul, B. 2007. Evaluation of fish mealfree diets for first feeding Nile Tilapia (Oreochromis niloticus). Journal of Applied Aquaculture, 19(3): 69-98.

Ismunaji, I. 2009. Peran Pakan Dalam Mendukung Budidaya Ikan. Disampaikan dalam Temu Pakan Nasional, Bandung, 19-20 Maret, 2009. Dirjen Budidaya Perikanan, 12 hlm.

Jackson, A.J., Capper, B.S., \& Matty, A.J. 1982. Evaluation of some plant protein in complete diets for the Tilapia, Sarotherodon mossambicus. J. Aquaculture, 27: 97-109.

Jauncey, K. \& Ross, B. 1982. A guide to Tilapia Feeds and Feeding. Institute of Aquaculture. University of Sterling-Scotland, 100 pp.
Kurniasih, T. 2010. Seleksi Bakteri Proteolitik dan Aplikasi Enzim Protease Untuk Meningkatkan Kualitas Pakan dan Kinerja Pertumbuhan Ikan Nila. Tesis. Sekolah Pascasarjana, IPB, $61 \mathrm{hlm}$.

Li, M.H. \& Robinson, E.H. 1998. Effects of supplemental lysine and methionine in low protein diets on weight gain and body composition of young channel catfish Ictalurus punctatus. Journal Aquaculture, 163: 297307.

Maulana, R. 2011 . Penggunaan Tepung Daun Lamtoro Sebagai Pengganti Tepung Bungkil Kedelai dalam Pakan Ikan Nila (Oreochromis niloticus). Jurusan Teknologi Budidaya dan Bisnis Perikanan. Fakultas Agribisnis dan Teknologi Pangan. Universitas Juanda, 52 hlm.

National Research Council (NRC). 1993. Nutrient Requirements of Warm Water Fishes. National Academy of Science. Washington D.C., 78 pp.

Rizal, Y., Djulardi, A., Peto, M., Rinawati, A., \& Wahyuni. 2005. Bioconversion of the Nutrient and HCN Conten of Cassava Leaves Under Aspergillus niger Fermentation. Stigma XIII No. 3, Juli-September 2005.

Standar Nasional Indonesia (SNI). 2009. Kumpulan Standar Nasional Indonesia (SNI). Direktorat Jenderal Perikanan Budidaya. Direktorat Produksi. Departemen Kelautan dan Perikanan, $72 \mathrm{hlm}$.

Subagyo, Prihadi, T. H., Jojo, S, Asih, S., \& Muharam, B. 1993. Pendederan Ikan Nila Merah Hasil Pengalihan Kelamin di Karamba Jaring Apung Waduk Kedungombo. Prosiding Seminar Hasil Penelitian Perikanan Air Tawar 1992/1993, hlm. 53-59.

Viola, S., Lahay, E. 1991. Effects of lysine supplementation in practical carp feeds on total protein sparing and reduction of pollution. Israel. J. Aquaculture, 43: 112-118.

Weatherly, A.M. 1972. Growth and Ecology of Fish Population. Acad. Pres. New York, London, $287 \mathrm{pp}$.

Wolfe, S.L. 1983. Biology of the Cell. Second Edition. Wadsworth Publishing Company, Belmont, California, 544 pp. 